\author{
A. Derevyanchenko, O. Fomin, V. Pavlenko, \\ N. Charugin, Odessa, Ukraine \\ ELEMENTS OF INFORMATION SUPPORT \\ OF CUTTING TOOLS DYNAMICS ANALYSIS
}

\begin{abstract}
The condition of the cutting part of the tool largely determines the quality of machining. Modern machine tools operate with limited operator participation, which necessitates the creation of automated systems for diagnosing tool conditions. An important part of this process is the development of mathematical and informational support, the creation of software classification systems - recognition of instrument states and their failures. The article presents an approach to the construction of decision trees and feature spaces that reflect the dynamics of the states of cutting tools (on the example of cutters).
\end{abstract}

Keywords: wear of the tools cutting part; diagnosing conditions; geometric features; feature space; decision trees.

Introduction. Modern engineering technologies are increasingly widespread in industry [1]. The corresponding machine tools (CNC machines, flexible manufacturing modules) are working with limited operator participation or completely autonomously. Most of their failures are due to gradual or sudden failures of cutting tools (CT), which necessitates the creation of appropriate automated or automatic diagnostic systems.

In such systems, the assessment of the degree of operability of the cutting part $(\mathrm{CP})$ of the tool based on signal processing from sensors of different physical nature.

CT wear as the tool operates leads to significant changes in its geometrical parameters, i.e. to the dynamics of the states of CT (efficient - prefailure - state of failure). It is obvious that it is necessary to develop mathematical and informational support for automatic classification (recognition, diagnosis) of the current states of CT, and prediction of the moment of failure.

When creating the necessary software complexes, the important elements are the formation and analysis of the corresponding decision trees, feature spaces that reflect the dynamics of the states of the CT. Therefore, the topic of the work seems to be relevant for the authors.

\title{
Literature review.
}

A large number of works by domestic and foreign researchers are devoted to the issues of monitoring and diagnosing the states of tools in the processes of their operation (or during periods of interruption of processing). 
Examples of the use "on-line" methods of direct and indirect control of tools working surfaces wear and the evaluation of the CT quality are shown in $[2,3]$.

A detailed review of modern methods of functional and test monitoring of instrument states made in [4].

On rough machining operations, methods of indirect control of instrument states and their dynamics are mainly used.

Here, the control object is not the directly worn cutting part, but certain data and signals generated by the cutting system recorded.

The methods based on the use of signal processing from sensors of different physical nature, for example, control of acoustic emission [5], forces and temperature of cutting, quality of the processed surface [6 - 8].

The use of methods for analyzing the corresponding signals using neural networks, a fuzzy logic apparatus, wavelet analysis and others shown in [8 12].

It noted that indirect methods of monitoring the states of the CT are mainly effective in the operations of roughing. They allow to quickly identify pre-refusal conditions, or failures and stop processing in time.

In the operations of finishing and precision processing, their accuracy, according to the authors, is not high enough. Here it seems advisable to perform direct CT monitoring performed during periods of treatment interruption or in the machine tool store using vision systems.

In considered sources, not enough attention (at our opinion) devoted to the mapping of information support for the analysis of the CT states dynamics. Therefore, a review and analysis of the literature allowed us to formulate the purpose and objectives of the work.

The purpose of the article is to develop elements of information support for the analysis of the tool states dynamics (in particular, cutters) under the conditions of direct control of their states.

The objectives of the article are:

1. Presentation of the approach to displaying the dynamics of the CT states in the spaces of wear zones geometric signs, failures and destruction of the cutting part;

2. Presentation of the approach to the construction of diagnostic decision trees (classification), reflecting the sequence of "dichotomous" recognition of each of the tool states.

\section{Research Methodology.}

The objects of state control were turning cutters for semi-finishing, finishing and precision turning, equipped with refillable carbide plate with TiN 
coating, and cutters, made of composites. Processing was made on lathes and boring machines.

The registration of the CT states (dynamics) sequence was made using special equipment with technical vision systems (TVS).

For each instrument, from the start of work until the moment of failure, a set of digital images of wear zones (at least 6 -7) was formed, reflecting the $\mathrm{CP}$ zone changing.

Sets of one of the stands are shown in Fig. 1 (stands and software developed with the participation of Ph.D. Krinitsyn D. A. and senior laboratory technician Volkov S.K.).
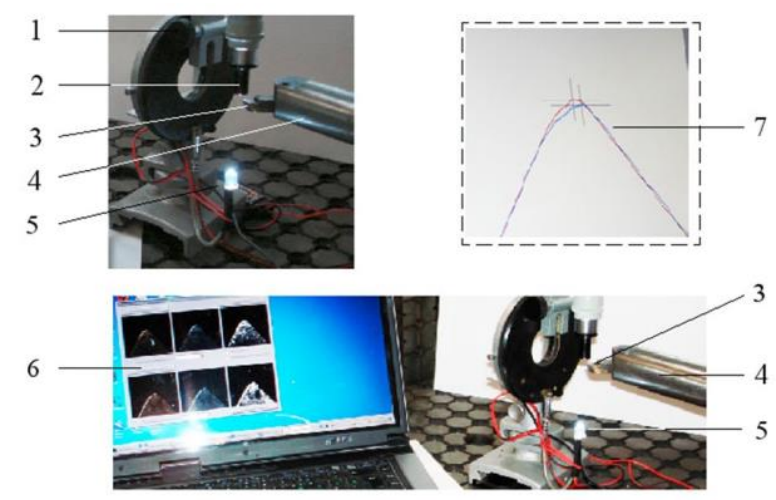

Figure 1 - Types of stand for registering sets of the cutting part images of the boring tool as it wears

On the rotary part of the body 1 was mounted digital camera 2 .

The cutting part of the boring cutter 3 installed in the boring bar 4 was illuminated by means of the light guide 5 (the corresponding projecting luminous flux was directed to the CT top.

Sets of digital images of the cutter front surface in various stages of their processing were displayed on the monitor of a personal computer 6 .

One of the stages of processing such images is the selection of the contours of the CT cutting edges for new and worn cutters. Their combination (7) allows to obtain information about the current value of radial wear and geometry of the transitional cutting edge.

Digital images of wear zones were processed, contour of wear zones, defects and $\mathrm{CP}$ micro defects were allocated, sets of corresponding geometric features were formed. They are the initial data for the construction of feature spaces in which zones (regions) of various classes of CT states are formed. 
To reduce the dimension (compression) of the feature space, we used special methods developed by us and described in $[14,15]$.

\section{Results.}

The basics of the approach to displaying the dynamics of the CT states in the spaces of the wear zones geometric signs, failures and destruction of the cutting part is shown in fig. 2 - 5 .

We introduce a series of notation and we write down some relations:

$X^{F}$ - space of signs of the shape of the contours of wear zones, defects and CP microdefects;

$X_{1}^{F}, X_{2}^{F}, X_{3}^{F}, \ldots, X_{n}^{F}$ - informative features of the shape of the contours of wear zones, defects and CP microdefects;

$\mathrm{n}$ - number of informative signs;

$A_{2}^{T}$ - working area of the flank surface of the worn cutter (the main object of control in conditions of fine and fine turning);

$\Omega_{1}^{F\left[A_{2}^{T}\right]}, \Omega_{2}^{F\left[A_{2}^{T}\right]}, \Omega_{3}^{F\left[A_{2}^{T}\right]}, \ldots, \Omega_{k}^{F\left[A_{2}^{T}\right]}$ - cutting state classes;

$k-\mathrm{CP}$ classes quantity;

$x_{F}^{T_{1}}, x_{F}^{T_{2}}, x_{F}^{T_{3}}, \ldots, x_{F}^{T_{p}}$ - vector signs of CP states, obtained at time points of control $T_{1}, T_{1}, T_{1}, \ldots, T_{p}$;

$K n^{L_{3}^{T}} \notin L_{3}^{T}$ - traces of concentrated wear are present on the flank surface of the CP (but do not affect the quality of the treated surface);

$K n^{L_{3}^{T}} \in L_{3 F}^{T}$ - traces of concentrated wear are present on the flank surface and reach the forming section of the cutting edge - $L_{3 F}^{T}$ (failure state - loss of surface quality);

$h_{Y}^{L_{0}^{T}},\left[h_{Y \max }^{L_{0}^{T}}\right]-$ respectively the current and limit value of the radial wear of the tool;

$h_{Y}^{L_{0}^{T}}<\left[h_{Y \max }^{L_{0}^{T}}\right]$ - radial wear value does not exceed the allowable;

$\operatorname{Pr}^{L_{21}^{T}}, \operatorname{Pr}^{L_{22}^{T}}$ - grooves respectively on the main and auxiliary flank surfaces of the CP;

$h_{\mathrm{Pr}}^{L_{2}^{T}}, h_{\mathrm{Pr}(\max )}^{L_{2}^{T}}$ - respectively, the current and marginal heights. 
$\operatorname{Pr}^{L_{21}^{T}} \notin L^{T}, \operatorname{Pr}^{L_{22}^{T}} \notin L^{T}$ - on the cutting part of the tool ( $L^{T}$ ) there are no grooves.

$N^{L_{1}^{T}}$ - built-up edge on the tools face surface ( $\left.L_{1}^{T}\right)$.

In fig. 2 the dynamics of the CP state are represented by five consecutive states.: $C_{1}^{L^{T}}-C_{5}^{L^{T}}$.

They are conventionally denoted by black circles - the tops of the state vectors $\left.x_{F}^{T_{1}}, x_{F}^{T_{2}}, x_{F}^{T_{3}}, \ldots, x_{F}^{T_{5}}\right)$, which belong to the three classes of $\mathrm{CP}$ states: $\Omega_{1}^{F\left[A_{2}^{T}\right]}, \Omega_{2}^{F\left[A_{2}^{T}\right]}, \Omega_{3}^{F\left[A_{2}^{T}\right]}$.

This corresponds to the set of relations (1):

$$
C_{1}^{L^{T}} \in \Omega_{1}^{F\left[A_{2}^{T}\right]} ; C_{2}^{L^{T}} \in \Omega_{1}^{F\left[A_{2}^{T}\right]} ; C_{3}^{L^{T}} \in \Omega_{2}^{F\left[A_{2}^{T}\right]} ; C_{4}^{L^{T}} \in \Omega_{1}^{F\left[A_{2}^{T}\right]} ; C_{5}^{L^{T}} \in \Omega_{3}^{F\left[A_{2}^{T}\right]} .
$$

Class $\Omega_{1}^{F\left[A_{2}^{T}\right]}$ - there are no grooves, concentrated wear and build-up on the worn out CP.

Class $\Omega_{2}^{F}\left[A_{2}^{T}\right]$ - traces of concentrated wear appeared on the CP, but they do not reach the forming section of the cutting edge; processing can continue.

Class $\Omega_{3}^{F\left[A_{2}^{T}\right]}$ - traces of concentrated wear reached the forming section of the cutting edge - a state of failure due to a loss in the quality of the machined surface.

Each of the states, except the parametric estimates, are represented by logical relations (conditions), given in curly brackets. They represent the appearance or absence of defects in the CP structure.

In fig. 3 The dynamics of the $\mathrm{CP}$ state are also represented by five consecutive states. : $C_{1}^{L^{T}}-C_{5}^{L^{T}}$.

Formula (2) indicate the CT failure states:

$$
h_{\operatorname{Pr}}^{L_{2}^{T}}>\left\lfloor h_{\operatorname{Pr}(\max )}^{L_{2}^{T}}\right\rfloor
$$

The dynamics of the CP state are represented by three states: $C_{1}^{L^{T}}-C_{3}^{L^{T}}$ in fig. 4.

Here the CT failure state is shown by the formula (3):

$$
N^{L_{1}^{T}} \in L^{T_{3}} \text {. }
$$




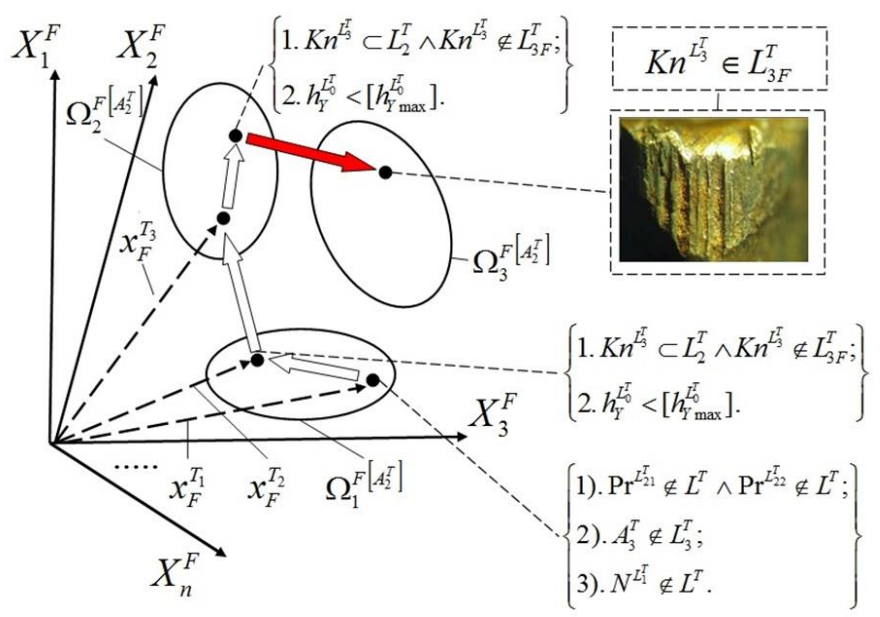

Figure 2 - Representation of the CP cutter states dynamics in the space of geometric features of the surface wear zone (the final CP state is a failure state due to the release of traces of concentrated wear to the cutting edge (CE) forming zone)

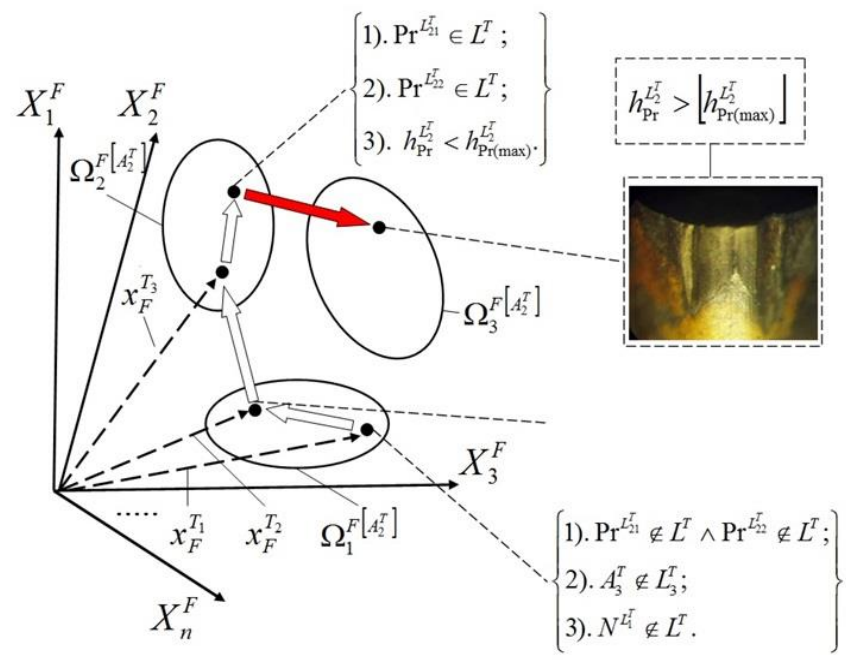

Figure 3 - Representation of the CP states dynamics in the space of geometric features of the surface wear zone (the final CP state is a failure state due to the development of 2 grooves) 


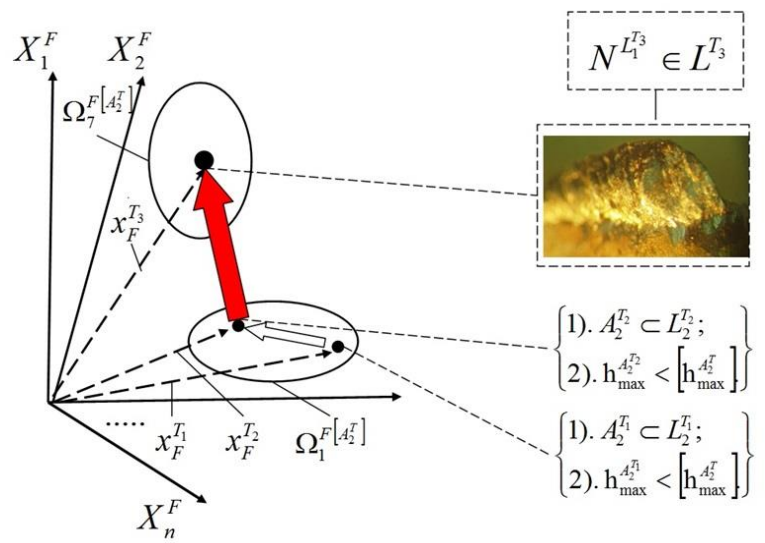

Figure 4 - Representation of the CP states dynamics in the space of geometric signs of the surface wear zone (the final CP state is the failure state of the built-up appearance)

Each of the reviewed $\left(C_{1}^{L^{T}}, C_{2}^{L^{T}}, C_{3}^{L^{T}}, \ldots, C_{5}^{L^{T}}\right)$ and other CP states are recognized using special classifiers $\left(K L F^{F r}\right)$. This process will present using "decision trees", i.e. graphs having a tree structure. Let us consider an approach to the construction of diagnostic decision trees (classification), reflecting the sequence of "dichotomic" - pairwise recognition of the belonging of states to pairs of classes.

In fig. 5 - 7 conventionally displayed processes of sequential formation of a decision tree for recognizing the CP state in the space of 5 classes.

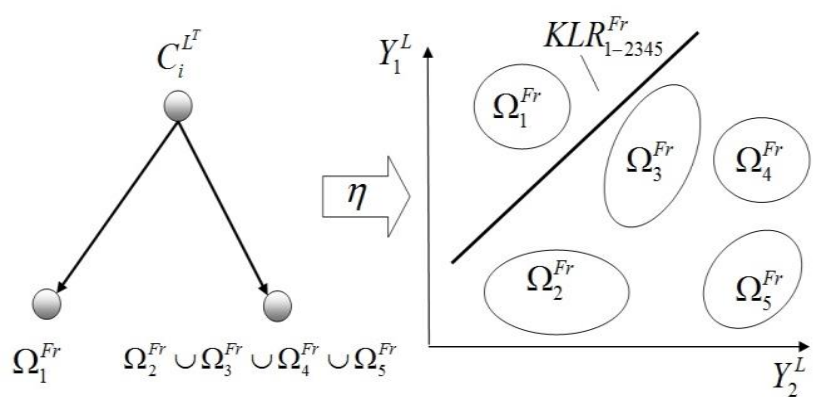

Figure 5 - Formation of a decision tree for the 1-st stage of the CT state recognition 


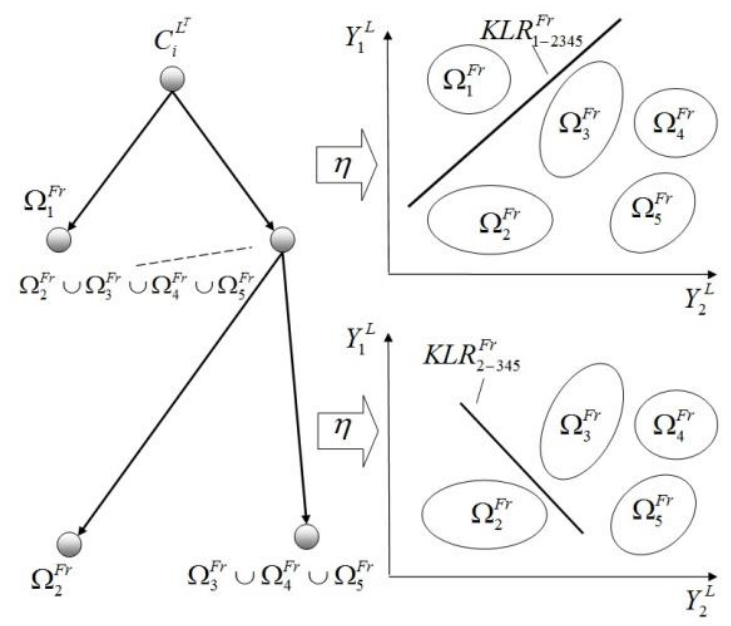

Figure 6 - Formation of a decision tree for the 1st and 2nd stages of the CP state recognition

To simplify the CP states classes diagrams are conventionally shown as disjoint, and classifiers $\left(K L F_{1-2345}^{F r}, K L F_{2-345}^{F r}, K L F_{3-45}^{F r}, K L F_{4-5}^{F r}\right)$ - linear.

The presented results allow us to proceed to the conclusions.

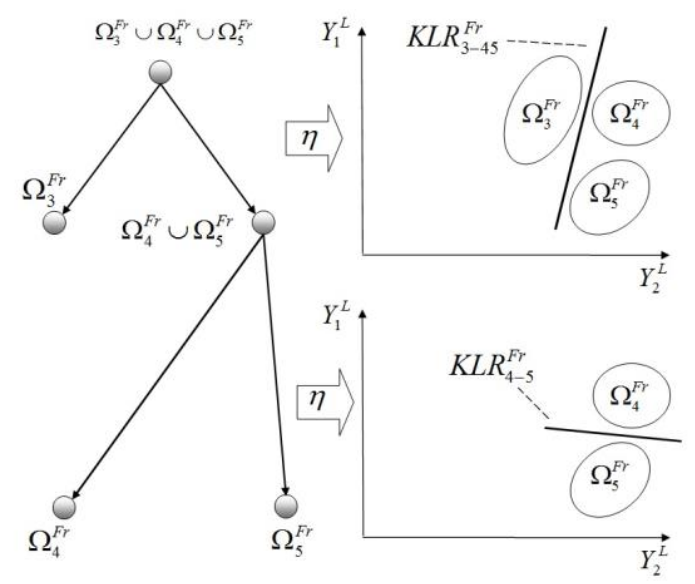

Figure 7 - Formation of a decision tree for the 3rd and 4th stages of the $\mathrm{CP}$ state recognition 


\section{Conclusions.}

1. Set out an approach to displaying the dynamics of the CT states in the spaces of wear zones geometric signs, failures of the CP.

2. Examples of the diagnostic decision trees (classifications) construction, reflecting the sequence of "dichotomous" recognition of each of the tool states are presented.

3. The obtained results will be the basis for the construction of automatic classifiers of the CP tools states.

References: 1. Mamalis,A. G.(2006). "Modern aspects of advanced manufacturing",Suchasni tehnologii u mashinobuduvanni [Сучасні технології у машинобудуванні],Vol, 2, Kharkiv, Ukraine, NTU "KhPI", pp. 58-73. 2. Lu Z., Ma, P., and other (February 2019). "On-line Monitoring of Tool Wear Conditions in Machining Processes Based on Machine Tool Data" Zhongguo Jixie Gongcheng, China Mechanical Engineering, Vol. 30, Issue 2, pp. 220-225. DOI: 10.3969/j.issn.1004-32X.2019.02.013. 3. Prokopyv N. M.,Bondarenko V. P and other(2008). Vlijanie uslovij spekanija splava VK10 OM nakinetikui mehanizmy iznosa ego v uslovijah chistovogo I udarnogo tochenija [Influence of sintering conditions of VK10 OM alloy on the kinetics and mechanisms of its wear under conditions of finishing and impact turning] Cutting and tooling in technological systems, Kharkiv, Ukraine, Vol. 75, pp. 312-327 [in Russian]. 4. Liang, S. Y., Hecker, R. L. and other. (May 2004). "Machining process monitoring and control: The state-ofthe-art". Journal of Manufacturing Science and Engineering, Transactions of the ASME, Vol. 126, Issue 2, pp. 297-310. DOI: 10.1115/1.1707035. 5. De Oliveira, J. F. G. \& Dornfeld, D. A. (2001). "Application of AE contact sensing in reliable grinding monitoring". CIRP Annals Manufacturing Technology, Vol. 50, Issue 1, pp. 217-220. DOI: 10.1016/S00078506(07)62108-8. 6. Sahu, N. K., Andhare, A. B., and other (May 2018). "Prediction of surface roughness in turning of Ti-6Al-4V using cutting parameters, forces and tool vibration" Materials Science and Engineering, Vol. 346, Issue 1. DOI: 10.1088/1757-899X/346/1/012037. 7. Kumar, P., Chauhan, S. R., and other (January 2019) "Influence of different grades of CBN inserts on cutting force and surface roughness of AISI H13 die tool steel during hard turning operation", Vol. 12, Issue 1. DOI: 10.3390/ma12010177. 8. Xie, Z., Li, J. and other(February 2019). "Feature selection and a method to improve the performance of tool condition monitoring" International Journal of Advanced Manufacturing Technology, Vol. 100, Issue 9-12, pp. 3197-3206. DOI: 10.1007/s00170018-2926-5. 9. Chungchoo, C \& Saini, D.(January 2019). "On-line tool wear estimation in CNC turning operations using fuzzy neural network model" International Journal of Machine Tools and Manufacture, Vol. 42, Issue 1, pp. 29-40. DOI: 10.1016/S0890-6955(01)00096-7. 10. Zhang, X., Tsang, W.-M., and other(February 2013). "A study on automatic on-machine inspection system for 3D modeling and measurement of cutting tools" Journal of Intelligent Manufacturing, Vol. 24, Issue 1, pp. 71-86. DOI: 10.1007/s10845-011-0540-6. 11. Saravanan, R., Asokan, P. and other (2001). "Comparative analysis of conventional and non-conventional optimization techniques for CNC turning process", International Journal of Advanced Manufacturing Technology, Vol. 17, Issue 7, pp. 471-476. DOI: 10.1007/s001700170146. 12. Dang, J., Liu, G., and other (May 2019). "Experimental investigation on machinability of DMLS Ti6Al4V under dry drilling process". Materials and Manufacturing Processes, Vol. 34, Issue 7, pp. 749-758. DOI: 10.1080/10426914.2019.1594254. 13. Rifai, A. P., Fukuda, R. and other (2019). "Image based identification of cutting tools in turning-milling machines" Japan Society for Precision Engineering., Vol. 85, Issue 2, pp. 159-166. DOI: 10.2493/jjspe.85.159. 14. Derevyanchenko, O.G., Pavlenko, V.D. and other. (1999). Diagnostirovanie sostojanij rezhushih instrumentov pri precizionnoj obrabotke [Diagnosing the states of cutting tools with precision machining], Odessa, Ukraine, Publ. Astroprint, 184 p. [in Russian]. 15. Derevyanchenko, O.G., Pavlenko, V.D., Fomin, 
O.O. and other (2013). Intellektual'nye sistemy raspoznavanija sostojanij rezhushh ihinstrumentov [Intelligent recognition systems for cutting tools], Odesa, Ukraine, Publ. Astroprint, 300 p. [in Russian].

\author{
О. Дерев`янченко, О. Фомін, В. Павленко, \\ М. Чаругін, Одеса,Україна
}

\title{
ЕЛЕМЕНТИ ІНФОРМАЦЙНОГО ЗАБЕЗПЕЧЕННЯ АНАЛІЗУ ДИНАМІКИ СТАНІВ РІЗЦІВ
}

\begin{abstract}
Анотація. Стан ріжучої частини інструменту в значній мірі визначає якість обробки різанням. Його характеризує комплекс параметрів $i$, в першу чергу, геометричні параметри ріжучої частини. В процесі обробки відбувається ії знос. Це призводить до значних змін параметрів внаслідок появи зон зносу на передній $i$ задній поверхнях, зсувів різальних кромок $i$ змін їх форми. Відсутність контролю за різальними інструментами призводить до поступових чи раптових їх відмов; руйнуванню інструментів та можливості виникнення аварій верстату. Сучасні металорізальні верстати прачюють за обмеженою участю оператора, що обумовлює необхідність створення автоматизованих систем моніторингу названих змін геометричних параметрів та діагностування станів інструментів. Важливою частиною цьвого процесу є розробка нових методів контролю інструментів, щчо забезпечують формування наборів інформативних параметрів, які відображають їх стан; математичного та інформаційного забезпечення, створення програмних комплексів класифікації-розпізнавання станів інструментів та їх відмов. У статті викладено підхід до побудови дерев рімень і просторів ознак, щчо відображають динаміку станів ріжучих інструментів (на прикладі різиів). Показані елементи нового підходу до відображення динаміки станів різального інструменту в просторах геометричних ознак зон зносу, відмов i руйнувань ріжучої частини. Наведені приклади побудови діагностичних дерев рімень (класифікачіï), ще відображають послідовність "дихотомічного" розпізнавання кожного $з$ станів інструменту. Отримані результати з'являться основою для побудови автоматичних класифікаторів станів ріжучої частини різиів та інших інструментів.
\end{abstract}

Ключові слова: знос ріжучої частини інструменту; діагностування станів; геометричні ознаки; простір ознак; дерева рімень. 